\title{
NTPrOBNP AND HRV AND OUTCOME IN PATIENTS WITH HEART FAILURE WITH REDUCED VS. PRESERVED SYSTOLIC FUNCTION
}

\author{
Nadya Stancheva ${ }^{1}$, Snezhana Tisheva ${ }^{1}$, Virginia Jordanova ${ }^{1}$, Stanimir Kurkchiev ${ }^{2}$, \\ Assen Goudev ${ }^{3}$ \\ 1) Clinic of Cardiology and Rheumatology, UMHAT "G. Stranski" - Pleven; \\ 2) Institute of Biology and Immunology of Reproduction, Bulgarian Academy of \\ Science - Sofia; \\ 3) Clinic of Cardiology with Intensive care Unit, UMHAT "Tsaritsa Ioanna" - \\ Sofia, Bulgaria.
}

\section{ABSTRACT:}

Background: Heart failure / $\mathrm{HF} /$ is usually associated with reduced systolic function. Elevated plasma concentrations of NTproBNP and heart rate variability /HRV/ are predictive of worse outcome in HF patients but there are few data about its predictive value in patients with HF and preserved systolic function.

Purpose and methods: The aim of this study was to determine the prognostic value of predischarge NT-proBNP and heart rate variability (HRV) in patients with reduced vs. preserved systolic function admitted for decompensated congestive HF. One hundred and twenty-seven patients were evaluated at the time of discharge by means of echocardiography, conventional laboratory tests, plasma for NTproBNP and Holter ECG for HRV. The primary endpoints of the study were defined as readmission for HF during the first 6 months after discharge, more than 2 hospitalizations for 1 year, or cardiac death.

Results: One hundred and twenty-one patients $/ 95.3 \% /$ were followed for mean of $387 \pm 117$ days. Fifty-four patients $144.6 \% /$ had reduced systolic function. Despite of the significant differences in the clinical characteristics of the patients with HF with reduced vs preserved systolic function, prognosis in both groups was poor. Predischarge NTproBNP levels were predictive of worse outcome irrespectively of the systolic function. Kaplan-Meier survival curves showed that NTproBNP $>300 \mathrm{pg} / \mathrm{ml}$ was associated with significantly worse outcome in both groups and $\mathrm{HRV}<20 \mathrm{~ms}$ was predictive of event occurrence in the reduced systolic function group. HRV reflected the severity of the systolic dysfunction in the reduced systolic function group.

Conclusions: In hospitalized HF patients predischarge NTproBNP levels are associated with poor prognosis in HF patients irrespective of systolic function while HRV reflects the severity and poor prognosis only of heart failure with reduced systolic function.
Key words: brain natriuretic peptide, heart rate variability, heart failure, prognosis

\section{INTRODUCTION.}

Heart failure $/ \mathrm{HF} /$ is usually the most frequent reason for morbidity, mortality and frequent rehospitalizations. [1-3] In order to optimize the healthcare for chronically ill patients researchers continuously search for new non-invasive methods of predicting the risk. The relationship between poor prognosis in chronic HF and neurohormones has already been established. [4-9] Neurohumoral activation is predictive of fatal and non-fatal cardiovascular events in patients with chronic HF. [10] A lot of authors confirm the role of brain natriuretic peptide /NTproBNP/ as a biochemical marker with high sensitivity and moderate specificity. Heart rate variability /HRV/ in HF is mainly predictive of the risk for cardiac death and pump failure. [11-14] Most studies on the prognostic value of HRV comprise patients with old myocardial infarction or ischemic heart disease with the presumption that the impaired autonomic control of cardiovascular system is one of the mechanisms of cardiac death, especially sudden cardiac death. [15-17] It is only recently that researchers have directed their efforts to establish the role of HRV in chronic HF. Usually HF is identified with systolic dysfunction and little is known about the prognosis of HF with preserved systolic function /HFPSF/. The aim of this study was to determine the prognostic value of predischarge NT-proBNP and HRV in patients with reduced vs. preserved systolic function HF.

\section{MATERIALAND METHODS.}

This study was approved by the local ethic committee of the Medical University of Pleven.

One hundred and twenty-seven patients who fulfilled the Framingham criteria for heart failure and were hospitalized in the Clinic of Cardiology and Rheumatology in the University Hospital 'Dr Georgi Stranski' in Pleven, Bulgaria 
participated in the sudy. All patients underwent chest X-ray, two-dimensional echocardiography, standard 12-lead ECG, and blood samples were taken for predischarge levels of NTproBNP, haemoglobin and creatinine. NTproBNP measurement was performed by means of immunoenzyme quantitative ELISA kit of Biomedica Gruppe in the Institute of Biology and Immunology of Reproduction, Bulgarian Academy of Science - Sofia. HRV was evaluated by means of 24-hour Holter ECG in 46 of the patients $/ 38.0 \%$ / in the day of discharge \pm 1 day with Cardiotens machine. Patients with no sinus rhythm were excluded from the analysis of HRV. The ECG readings were manually inspected, and all the intervals containing artifacts and ectopic beats were excluded being replaced by the preceding normal RR intervals. All time HRV indices were measured and calculated automatically. Patients were divided into two groups - I group of patients with HF and reduced systolic function /HFRSF/ defined as ejection fraction $/ \mathrm{EF} /<40 \%$ and group II of the patients with heart failure and preserved systolic function /HFPSF/ defined as $E F \quad \geq 40 \%$. The primary endpoints of the study were defined as readmission for HF during the first 6 months after discharge, more than 2 hospitalizations for 1 year, or cardiac death.

\section{RESULTS}

One hundred and twenty-one of the patients $/ 95.3 \% /$ were followed for mean of $387 \pm 117$ days. Of them 54 patients $165.3 \% /$ had reduced systolic function. The main quantitative and qualitative characteristics of both groups are shown in tables 1 and 2 respectively.

The minimal predischarge value of NTproBNP in patients with HFRSF was $61,695 \mathrm{pg} / \mathrm{ml}$, the maximal was $1951,49 \mathrm{pg} / \mathrm{ml}$. The median value of NTproBNP was 249.839 $\mathrm{pg} / \mathrm{ml}$. By means of non-parametric percentile method 3 groups were formed according to the plasma levels of NTproBNP, presented in table 3. There was significant difference in the concentration of NTproBNP /respectively 283.4 and 123.7, Kruskal-Wallis test $=11.28, \mathrm{p}<0.001 /$ in the event and non-event group, figure 1. There was also significant difference between the median value of NTproBNP of those who died and those who survived /respectively 573.4 versus 202.8, Kruskal-Wallis test $=11.35, \mathrm{p}<0.001 /$. Patients who were rehospitalized within 6 months of discharge had significantly higher plasma concentration of NTproBNP than those who were not /respectively 331.8 versus 167.8 , KruskalWallis test $=11.62, \mathrm{p}<0.001 /$. Similar result was obtained when comparing the group of patients with more than 2 heart failure hospitalizations for one year and those who were not hospitalized /NTproBNP respectively 329.6 versus 146.0, Kruskal-Wallis test $=16.15, \mathrm{p}<0.001 /$.

The minimal predischarge value of NTproBNP in patients with HFPSF was $19.313 \mathrm{pg} / \mathrm{ml}$, the maximal was $1615.18 \mathrm{pg} / \mathrm{ml}$. The median value of NTproBNP was 124.935 $\mathrm{pg} / \mathrm{ml}$. By means of non-parametric percentile method 3 groups were formed according to the plasma levels of NTproBNP, presented in table 4. There was significant difference between the concentration of NTproBNP / respectively 168.5 versus 120.0 , Kruskal-Wallis test $=9.55, p$ $<0.01$ / in the event and non-event group, figure 2. There was also significant difference between the median value of NTproBNP of those who died and those who survived / respectively 333.8 versus 123.1 , Kruskal-Wallis test $=6.58, \mathrm{p}$ $=0.01 /$. Between patients who were rehospitalized within 6 months of discharge and those who were not there was not statistical difference in the plasma concentration of NTproBNP/respectively 150.3 versus 124.2 pg/ml, KruskalWallis test $=1.30, p=0.25 /$. At the same time when comparing the group of patients with more than 2 heart failure hospitalizations for one year and those who were not hospitalized there was statistical difference in NTproBNP plasma concentration /respectively 224.9 versus $121.0 \mathrm{pg} / \mathrm{ml}$, Kruskal-Wallis test $=10.26, \mathrm{p}<0.01 /$.

Kaplan-Meier event-free survival curves in the three groups according to NTproBNP plasma concentration in HFRSF and HFPSF are shown on figure 3 and figure 4. There was significant difference in the survival rate in the three NTproBNP subgroups both in HFRSF and HFPSF.

When comparing the different HRV indices in HFRSF and HFPSF it was evident that there was no relationship between SDNN and systolic function/respectively $91 \mathrm{~ms}$ in HFRSF and $99 \mathrm{~ms}$ in HFPSF, Kruskal-Wallis test $=0.5, \mathrm{p}=$ $0.5 /$. There was statistically significant difference between the time HRV indices SDNN, SDANN, SDNNindex, HRVti and TINN in the HFRSF group, table 5. There was no significant difference between the median value of SDNN in the group of the non-survivals versus the survivals /respectively 63 versus $91 \mathrm{~ms}$, Kruskal-Wallis test $=1.89, \mathrm{p}=0.17 /$. There was not statistical difference in both time and frequency HRV indices between patients with HFRSF who were rehospitalized within 6 months after discharge and those who were not. At the same time patients who were hospitalized at least twice for a period of one year had significantly lower HRV as compared to those who were not hospitalized /SDNN respectively 63 versus $91 \mathrm{~ms}$, Kruskal-Wallis test $=3.63, \mathrm{p}<$ $0.05 /$. In HFPSF patients there was no difference in any of the HRV indices between the event and event-free group and between the rehospitalized patients within 6 months after discharge and those who were not hospitalized. The same result was obtained when comparing the non-survival and survival group /SDNN respectively 75 versus $106 \mathrm{~ms}$, Kruskal-Wallis test $=1.57, \mathrm{p}=0.2 /$, but as one can see there was a tendency of lower HRV in the non-survival group. When comparing the group of HFPSF patients with more than 2 heart failure hospitalizations for one year and those who were not hospitalized there was not statistical difference in HRV values /SDNN respectively 67 versus 110 ms, KruskalWallis test $=1.7, p=0.2 /$. Kaplan-Meier event-free survival curves for patients with HFRSF showed worse survival rate 
with lower $\mathrm{HRV} / \mathrm{HRVti}<20$ /, figure 5. There was no significant difference in the survival rate of patients with HFPSF dependent on HRV indices.

\section{DISCUSSION.}

Patients with HF and preserved systolic function represent a distinct group of patients with their typical characteristics. These are patients who very often do not fall among the randomized patients in big clinical trials as patients with reduced systolic function do. As a result of this there is very small amount of scientific data concerning the characteristics, treatment and prognosis of this group of patients. Furthermore, it turns out that these patients differ in their clinical presentations from the patients with HFRSF. In our study we put emphasis not only on the clinical characteristics but even more on the prognostic importance of neurohumoral activation presented by NTproBNP and heart rate variability in patients with HFPSF as compared to HFRSF. The endpoint of cardiac death cannot be trustfully evaluated in this small study with a very low rate of death cases occurred. What results really show is that in both groups the frequency of primary endpoints is very high. Outcome in patients with HFPSF seems to be more favorable but $19.4 \%$ of the patients with HFPSF were hospitalized at least twice for a period of 1 year, and nearly $12 \%$ of them were rehospitalized within 6 months after discharge.

\section{CONCLUSIONS.}

1. Despite the significant differences in the clinical characteristics of the patients with HFRSF and HFPSF prognosis in both groups is poor.

2. Predischarge plasma concentration of NTproBNP is an independent prognostic marker both in HFRSF and HFPSF. Kaplan-Meier NTproBNP dependent survival curves show that both in HFRSH and HFPSH predischarge NTproBNP levels greater than $300 \mathrm{pg} / \mathrm{ml}$ are connected with a significantly lower rate of survival.

3. Heart rate variability reflects to a certain degree the severity of HFRSF. Heart rate variability is an independent prognostic marker in HFRSF, but not in HFPSF.

\section{Limitations of the study.}

Only 121 patients took part in the study, but the percentage of reached at least one endpoint was high $/ 45 \% /$ . The population consisted of mainly young patients with high incidence of diabetes mellitus and arterial hypertension, which fact necessitates validation of the results in a big prospective study. The impact of therapy on NTproBNP and HRV has not been taken into account due to financial reasons and this will be object of further investigations.

Table 1. Comparison of main qualitative characteristics according to systolic function.

\begin{tabular}{|l|c|c|c|c|c|c|}
\hline \multirow{2}{*}{\multicolumn{1}{|c|}{ Characteristics }} & \multicolumn{2}{c|}{ HFRSF/n=54/ } & \multicolumn{2}{c|}{ HFPS/n=67/ } & \multicolumn{2}{c|}{ Comparison } \\
\cline { 2 - 7 } & $\mathrm{n}$ & $\%$ & $\mathrm{n}$ & $\%$ & $\begin{array}{c}\text { Student's t } \\
\text { criterion }\end{array}$ & $\mathrm{p}$ value \\
\hline Male & 42 & 77.8 & 27 & 40.3 & 4.88 & $\mathrm{p}<0.001$ \\
\hline Diabetes mellitus type 2 & 18 & 33.3 & 19 & 28.4 & 0.32 & $\mathrm{NS}$ \\
\hline Arterial hypertension & 41 & 75.9 & 59 & 88.1 & 1.77 & $\mathrm{p}<0.05$ \\
\hline Anemia & 12 & 22.2 & 16 & 23.9 & 0.1 & $\mathrm{NS}$ \\
\hline COPD & 7 & 12.96 & 16 & 23.9 & 0.66 & $\mathrm{NS}$ \\
\hline Ischaemic etiology & 46 & 85.2 & 40 & 59.7 & 2.72 & $\mathrm{p}<0.01$ \\
\hline Myocardial infarction & 23 & 42.6 & 9 & 13.4 & 1.9 & $\mathrm{p}<0.05$ \\
\hline Segment kinetic disturbances & 45 & 83.3 & 17 & 25.3 & 4.87 & $\mathrm{p}<0.001$ \\
\hline With event & 36 & 66.7 & 18 & 26.9 & 3.05 & $\mathrm{p}<0.001$ \\
\hline Non-survivals & 13 & 24.1 & 5 & 7.5 & 0.99 & $\mathrm{NS}$ \\
\hline $\begin{array}{l}\text { Rehospitalized within } \\
6 \text { months after discharge }\end{array}$ & 29 & 53.7 & 8 & 11.9 & 2.84 & $\mathrm{p}<0.01$ \\
\hline $\begin{array}{l}\text { With at least } \\
\text { 2 hospitalizations for 1 year }\end{array}$ & 33 & 61.1 & 13 & 19.4 & 3.01 & $\mathrm{p}<0.01$ \\
\hline
\end{tabular}


Table 2. Comparison of main quantitative characteristics according to systolic function.

\begin{tabular}{|c|c|c|c|c|}
\hline \multirow{2}{*}{ Characteristics } & \multirow{2}{*}{$\begin{array}{l}\text { HFRSF } \\
/ \mathrm{n}=54 /\end{array}$} & \multirow{2}{*}{$\begin{array}{l}\text { HFPSF } \\
/ \mathrm{n}=67 /\end{array}$} & \multicolumn{2}{|l|}{ Comparison } \\
\hline & & & Criterion & $\mathrm{p}$ value \\
\hline Age /mean $\pm \mathrm{SD} /$ & $62.5 \pm 7.6$ & $64.1 \pm 8.4$ & $\mathrm{~F}=1.09$ & $\mathrm{NS} / 0.3 /$ \\
\hline $\mathrm{EF} / \% /$ & $28.96 \pm 7.7$ & $53.9 \pm 7.6$ & $\mathrm{~F}=319.5$ & $<0.0001 / \mathrm{NA}$ \\
\hline $\begin{array}{l}\text { NTproBNP } \\
\text { /median value/ }\end{array}$ & 249.839 & 124.935 & $\begin{array}{c}\text { Kruskal-Wallis test } \\
=21.6\end{array}$ & $<0.0001$ \\
\hline $\begin{array}{l}\text { TNF-б } \\
\text { /median value/ }\end{array}$ & 3.1681 & 3.5542 & $\begin{array}{c}\text { Kruskal-Wallis test } \\
=0.23\end{array}$ & NS /0.63/ \\
\hline Haemoglobin /g/l/ & $135 \pm 20.1$ & $130 \pm 18.0$ & $\mathrm{~F}=1.59$ & $\mathrm{NS} / 0.2 /$ \\
\hline Creatinine /Mg/l/ & $103 \pm 17.8$ & $97 \pm 19.9$ & $\mathrm{~F}=3.55$ & $\mathrm{NS} / 0.06 /$ \\
\hline Sodium $/ \mathrm{mmol} / \mathrm{l} /$ & $141 \pm 4.2$ & $142 \pm 4.0$ & $\mathrm{~F}=0.6$ & NS /0.43/ \\
\hline Potassium $/ \mathrm{mmol} / \mathrm{l} /$ & $4.8 \pm 0.78$ & $4.75 \pm 0.71$ & $\mathrm{~F}=0.25$ & $\mathrm{NS} / 0.62 /$ \\
\hline
\end{tabular}

Table 3. Subdivision of patients with HFRSF according to the plasma concentration of NTproBNP.

\begin{tabular}{|c|c|c|c|}
\hline NTproBNP $/ \mathrm{pg} / \mathrm{ml} /$ & Number of patients & Frequency $/ \% /$ & Cumulative frequency \\
\hline$\leq 100$ & 5 & 9.3 & 5 \\
\hline $101-300$ & 27 & 50.0 & 32 \\
\hline$\geq 301$ & 22 & 40.7 & 54 \\
\hline
\end{tabular}

Table 4. Subdivision of patients with HFPSF according to the plasma concentration of NTproBNP.

\begin{tabular}{|c|c|c|c|}
\hline NTproBNP $/ \mathrm{pg} / \mathrm{ml} /$ & Number of patients & Frequency $/ \% /$ & Cumulative frequency \\
\hline$\leq 100$ & 19 & 28.4 & 19 \\
\hline $101-300$ & 40 & 59.7 & 59 \\
\hline$\geq 301$ & 8 & 11.9 & 67 \\
\hline
\end{tabular}

Table 5. Comparison between different HRV indices in the event-free and event groups in HFRSF.

\begin{tabular}{|c|c|c|c|c|}
\hline \multirow[t]{2}{*}{ HRV index } & \multirow[t]{2}{*}{ Event-free $/ \mathrm{n}=7 /$} & \multirow[t]{2}{*}{ With event $/ \mathrm{n}=15 /$} & \multicolumn{2}{|c|}{ Comparison } \\
\hline & & & Criterion & $\mathrm{p}$ value \\
\hline $\mathrm{SDNN} / \mathrm{ms} /$, median & 91.0 & 63.0 & Kruskall-Walis test $=3.63$ & $\mathrm{P}<0.05$ \\
\hline $\mathrm{SDANN} / \mathrm{ms} /$, median & 131.0 & 80.0 & Kruskall-Walis test $=5.92$ & $\mathrm{P}<0.05$ \\
\hline SDNNindex, median & 51.0 & 27.0 & Kruskall-Walis test $=5.1$ & $\mathrm{P}<0.05$ \\
\hline $\mathrm{SDSD} / \mathrm{ms} /$, median & 32.0 & 29.0 & Kruskall-Walis test $=1.8$ & NS \\
\hline pNN50 /\%/, median & 6.0 & 3.0 & Kruskall-Walis test $=2.03$ & NS \\
\hline HRVti, median & 28.0 & 14.0 & Kruskall-Walis test $=5.44$ & $\mathrm{P}<0.05$ \\
\hline $\mathrm{TINN} / \mathrm{ms} /$, median & 432.0 & 225.0 & Kruskall-Walis test $=5.25$ & $\mathrm{P}<0.05$ \\
\hline $\mathrm{rMSSD} / \mathrm{ms} /$, median & 32.0 & 29.0 & Kruskall-Walis test $=1.7$ & NS \\
\hline LF, median & 246.5 & 143.3 & Kruskall-Walis test $=0.55$ & NS \\
\hline HF, median & 237.4 & 169.4 & Kruskall-Walis test $=0.32$ & NS \\
\hline LF/HF, median & 1.0 & 0.9 & Kruskall-Walis test $=0.56$ & NS \\
\hline Total power, median & 1542.0 & 610.0 & Kruskall-Walis test $=1.39$ & NS \\
\hline
\end{tabular}




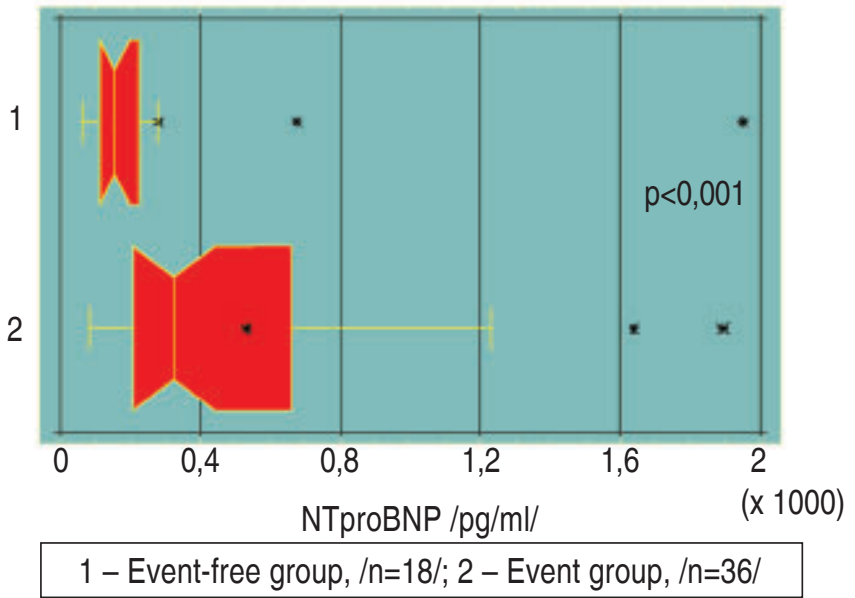

Figure 1. Comparison between the NTproBNP median value in the event-free /1/ and event group /2/ in HFRSF.

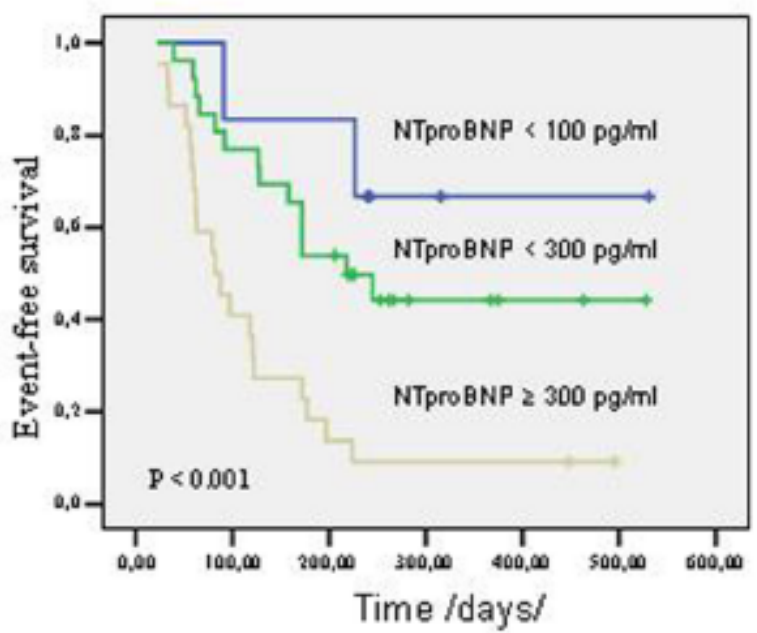

Figure 3. NTproBNP in patients with HFRSF: KaplanMeier event-free survival curves.

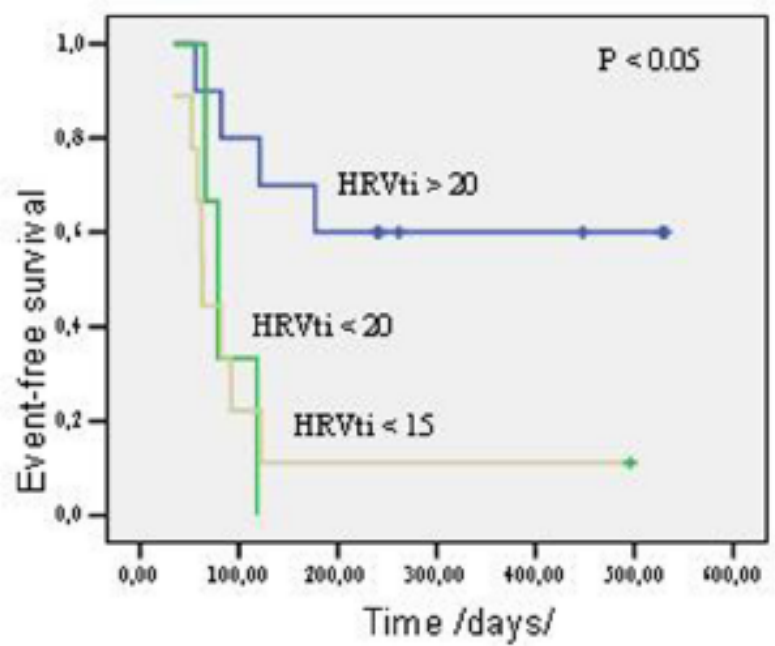

Figure 5. HRV in patients with HFRSF: Kaplan-Meier event-free survival curves.

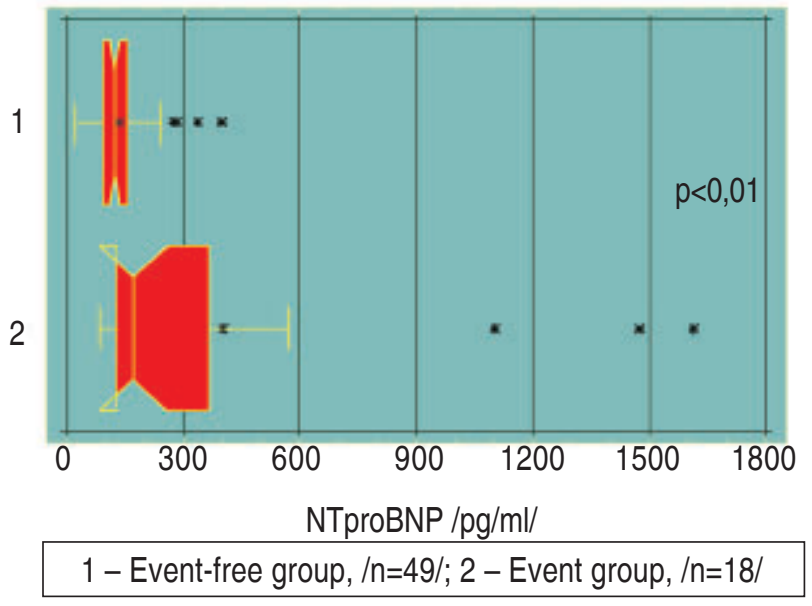

Figure 2. Comparison between the NTproBNP median value in the event-free /1/ and event group /2/ in HFPSF.

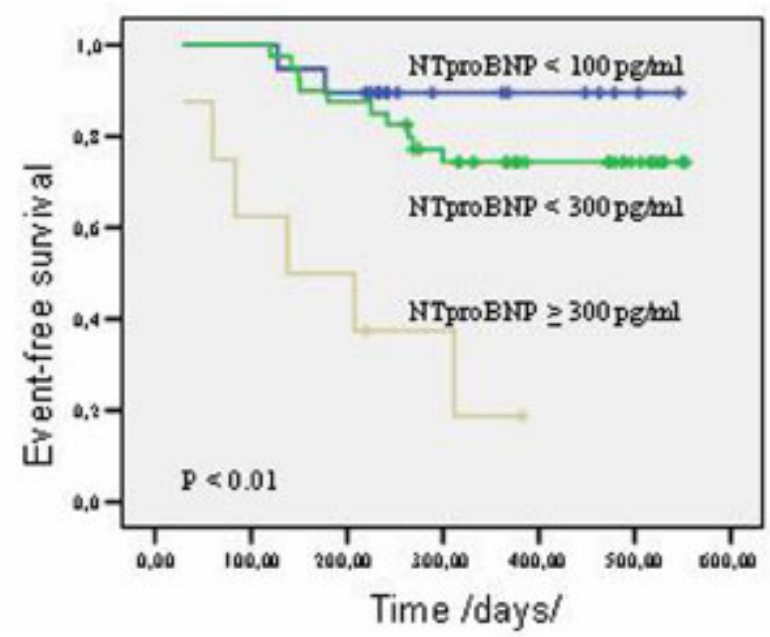

Figure 4. NTproBNP in patients with HFPSF: KaplanMeier event-free survival curves. 


\title{
Acknowledgements:
}

This study was conducted with the financial help of fund „Scientific research" of the Ministry of Education and Science of Bulgaria.

\section{REFERENCES:}

1. Cowie MR, Mosterd A, Wood DA, Deckers JW, Poole-Wilson PA, Sutton $\mathrm{GC}$, et al. The epidemiology of heart failure. Eur Heart J. 1997 Feb;18(2):208225. [PubMed]

2. Braunwald E. Heart Failure. In: Brauwald et al. Harrison's principles of internal medicine. $15^{\text {th }}$ ed. New York, McGraw-Hill, 2001:1318-1331.

3. Ho KK, Anderson KM, Kannel WB, Grossman W, Levy D. Survival after the onset of congestive heart failure in Framingham Heart Study subjects. Circulation. 1993 Jul;88(1): 107-115. [PubMed] [CrossRef]

4. Abassi Z, Karram T, Ellaham S, Winaver J, Hoffman A. Implications of the natriuretic peptide system in the pathogenesis of heart failure\& diagnostic and therapeutic importance. Pharmacol Ther. 2004 Jun;102(3):223241. [PubMed] [CrossRef]

5. Dokainish H, Zoghbi WA, Lakkis NM, Ambriz E, Patel R, Quinones MA, et al. Incremental predictive power of Btype natriuretic peptide and tissue Doppler echocardiography in the prognosis of patients with congestive heart failure. $J$ Am Coll Cardiol. 2005 Apr 19;45(8):1223-26. [PubMed] [CrossRef]

6. Logeart D, Thabut G, Jourdain P, Chavelas C, Beyne P, Beauvais F, et al. Predischarge B-type natriuretic peptide assay for identifying patients at high risk of readmission after decompensated heart failure. J Am Coll Cardiol. 2004 Fer 18;43(4):645-41. [PubMed] [CrossRef]

7. Gardner RS, Ozalo F, Murday AY,
Robb SD, McDonagh TA. N terminal pro-brain natriuretic peptide. A new gold standard in predicting mortality in patients with advanced heart failure. Eur Heart J. 2003 Oct;24(19):1735-43. [PubMed] [CrossRef]

8. Hunt PJ, Richardis AM, Nicholls MG, Yandle TG, Doughty RN, Espiner EA. Immunoreactive amino-terminal probrain natriuretic peptide (NT-proBNP): a new marker of cardiac impairment. Clin Endocrinol (Oxf) 1997 Sep;47(3):287-96. [PubMed]

9. Ambrose TM. A review of the clinical utility of NTproBNP in the diagnosis, prognosis, and therapy monitoring of patients with congestive heart failure. J Clin Ligand Assay. 2003; 25:160-6.

10. Richards AM, Doughty R, Nicholls MG, et al. Plasma N-terminal pro-brain natriuretic peptide and adrenomedullin: prognostic utility and prediction of benefit from carvedilol in chronic ischaemic left ventricular dysfunction. Australia-New Zealand Heart Failure Group. J Am Coll Cardiol. 2001; 37(7):1781-7.

11. Brouwer J, van Veldhuisen DJ, Man in ' $t$ Veld AJ, Haaksma J, Dijk WA, Visser KR, et al. Prognostic value of heart rate variability during long-term follow-up in patients with mild to moderate heart failure. The Dutch Ibopamine Multicenter Trial Study Group.J Am Coll Cardiol. 1996 Nov 1;28(5):1183-1189. [PubMed] [CrossRef]

12. Counihan PJ, Fei L, Bashir Y, Farrell TG, Haywood GA, McKenna WJ. Assessment of heart rate variability in hypertrophic cardiomyopathy. Association with clinical and prognostic features. Circulation. 1993 Oct;88(4 Pt 1):1682-1690. [PubMed] [CrossRef]

13. Mortara A, Tavazzi L. Prognostic implications of autonomic nervous system analysis in chronic heart failure: role of heart rate variability and baroreflex sensitivity. Arch Gerontol Geriatr. 1996 Nov-Dec;23(3):265-275. [PubMed] [PubMed]

14. Takase B, Kurita A, Noritake M, Uehata A, Maruyama T, Nagayoshi H, et al. Heart rate variability in patients with diabetes mellitus, ischemic heart disease, and congestive heart failure. $J$ Electrocardiol. 1992 Apr;25(2):79-88. [PubMed] [CrossRef]

15. Woo MA, Stevenson WG, Moser DK, Trelease RB, Harper RM. Patterns of beat-to-beat heart rate variability in advanced heart failure. $\mathrm{Am}$ J Cardiol. 1992 Mar;123(3):704-710. [PubMed] [CrossRef]

16. Lombardi F, Makikallio TH, Myerburg RJ, Huikuri HV. Sudden cardiac death: role of heart rate variability to identify patients at risk. Cardiovascular Research. 2001 May;50(2):210-217. [PubMed] [CrossRef]

17. Task Force of the European Society of Cardiology and the North American Society of Pacing and Electrophysiology. (Marek Malik, writing chairman.) Heart rate variability standards of measurement, physiological interpretation, and clinical use. Circulation. 1996; 93:1043-1065.

\author{
Adress for corespondence: \\ Nadya Stancheva \\ Clinic of Cardiology and Rheumatology; UMHAT Georgi Stranski \\ 8 A Georgi Kochev str., 5800 Pleven, Bulgaria \\ Tel. +359 64886 140; +359 887749 946; Fax: +359 64886370 \\ e-mail: nadia_stancheva@abv.bg;
}

